\title{
Performing Shakespeare in a Conflicting Cultural Context: Othello in Francoist Spain ${ }^{1}$
}

\author{
Elena Bandín Fuertes \\ Universidad de Murcia
}

\begin{abstract}
The present article reviews the stage history of Othello in Spain and, in particular, it focuses on two performances of the play staged at the Español theatre during Franco's dictatorship, in 1944 and 1971 respectively. Othello was one of the Shakespearean plays programmed by the regime to give cultural prestige to the "national" theatre. By comparing both productions, this paper explores how the performance of Othello evolved during the dictatorship. Furthermore, it shows how the repressive force of state censorship was exerted to promote certain theatrical conventions and to prevent theatre directors and translators from offering new readings and updatings of the plays, in the case of Othello, for almost thirty years.
\end{abstract}

KEYWORDS: Othello, Franco's dictatorship, national theatre, censorship, translation.

We can trace the stage history of Othello in Spain back to 1802, when Isidoro Máiquez embodied the Moor in Teodoro de la Calle's untidy translation of the highly acclaimed French version by Ducis. ${ }^{2}$ The rendering of Ducis's version, written in the shape of an epic romance, became the most popular Shakespearean play on the

\footnotetext{
${ }^{1}$ The research for this paper was funded by the projects "La presencia de Shakespeare en España en el marco de su recepción europea" (FFI-2008-01969) and "Traducciones censuradas (TRACE 1939-1985): estudios sobre catálogos y corpus" (FFI-2008-05479Co2-01). I am grateful to the Spanish Ministry of Science and Innovation for its support.

${ }^{2}$ It now seems clear for many scholars that Teodoro de la Calle is the pseudonym often used by José María de Carnerero (see Gregor 2010:17-25).
}

(C) ederi 21 (2011): 119-132

https://doi.org/10.34136/sederi.2011.6 
Spanish stage during the first three decades of the nineteenth century (Calvo 2006a). This Otelomania, as Calvo points out,

indicates that there was at least one Shakespearean play that Spanish actors, theatre managers, and audiences quickly appropriated and dealt with as if it belonged to their native theatrical tradition. Otelo was "the Other" because he was a foreigner, but he was not a complete stranger to Spanish audiences used to adaptations of the plays of Calderón and other Golden Age playwrights obsessed with male-female relationships in which male honor feels threatened by the suspicion of female lack of virtue. (2006a:119)

This process of appropriating the Shakespearean play took a step further between 1828 and 1844, when the neoclassical DucisCarnerero tragedy of Othello was rewritten as comedy, in the comic one-act form of a Spanish sainete in which Otelo became "el Caliche", a mocking low-born Spaniard from Valencia, Macarena or Madrid depending on the versions, a humorous jealous husband from the working class very familiar to the Spanish audiences. Surprisingly, Carnerero himself signed some of these famous burlesques, such as Sainete Nuevo, titulado Caliche, ó el Tuno de Macarena in 1828 or Caliche, la parodia de Otelo. Sainete Trágico in 1831 (Gregor 2010:34). ${ }^{3}$ These strategies of cultural appropriation and naturalisation to transfer the play could explain the popularity of Othello on nineteenth-century Spanish stages. Par (1936-1940) registered forty-four performances in Madrid and eighty in Barcelona between 1802 and 1886. Apart from the success achieved on stage, Othello was also the most frequently translated Shakespearean play at the time, as ten different Spanish translations were published and continuously reprinted in the nineteenth century. ${ }^{4}$

Moving forward to the first decades of the twentieth century, we find the highly acclaimed performance of Otelo at the Español theatre in 1936, with Enrique Borrás and Ricardo Calvo in the

\footnotetext{
${ }^{3}$ For an exhaustive study of El Caliche see Calvo (2006a; 2006b) and Gregor (2002; 2010:34-37).

${ }^{4}$ Serrano (1988:19), following Par, enumerates the following six translations: Teodoro de la Calle (1802), Francisco Luis de Retés (1868), Laureano Sánchez Garay (1868), Matías de Velasco y Rojas (1869), Jaime Clark (1870-1876) and Guillermo Macpherson (1873). This work relies on the information compiled by Laura Campillo for the SHESTRA database (www.um.es/shakespeare/shestra).
} 
leading roles of a production based on Luis Astrana Marín's prose translation, from which many adaptations of the period derived. ${ }^{5}$

During Franco's dictatorship, the Español theatre became one of the sites of the "national" theatre, whose repertoire mainly consisted of the classics of Spanish Golden Age drama and world classical plays. $^{6}$ The starting signal was Felipe Lluch's 1940 production España, una, grande y libre to celebrate the first anniversary of Franco's victory. Felipe Lluch, together with Tomás Borrás, presented the project on which the ideological principles of the national theatre were founded. Lluch was aware of the need for a technical renovation in the theatre and for finding new modes of direction and production. He also considered the role of the stage director essential inasmuch as this figure was mainly responsible for the achievements of a "national" theatre. Lluch's successor would be Cayetano Luca de Tena, who would be at the head of the Español for the next ten years, from 1942 to 1952 . With an evidently conservative motivation, Shakespeare's plays - mainly tragedies - were regularly staged at the Español to serve the propaganda interests of the regime in promoting a "national" theatre. During the post-war period, Cayetano Luca de Tena produced Macbeth (1942), Romeo and Juliet (1943), Othello (1944), A Midsummer Night's Dream (1945), Richard III (1946), The Merchant of Venice (1947) and Hamlet (1949), commissioning all the translations to Nicolás González Ruiz, except for Hamlet. This appropriation of Shakespeare was partly achieved by neutralising any political reading of his works, as Gregor and Bandín point out,

The potentially subversive nature of some of these tragedies [...] was neutralized by having them doctored by self-censoring authors and, perhaps more decisively, by staging them in such a way that the texts' political context could be viewed as distant, both temporally and spatially, from the "time-space" of mid $20^{\text {th }}$ century Spain. The insistence in contemporary reviews of the performances on the "exterior" trappings of costume, music as well as the spectacular mises-en-scène, were a further guarantee

\footnotetext{
${ }^{5}$ El Sol, 22/02/1936, p. 5. Luis Astrana Marín was the first to translate the complete works by Shakespeare.

${ }^{6}$ For a history of the Spanish "national" theatres see Peláez (1993-1995). See also the works by Gregor (2007) and Bandín (2008) on Shakespeare at the Español.
} 
against "dissident" readings instilling themselves in potential spectators of the play. (Gregor and Bandín, forthc.)

The demand for contemporary reviews to avoid "dissident" readings is frequently found in every phase of a process that we can call a pre- and post-production propaganda campaign that aimed at placing the Spanish national theatre at the level of its counterparts in Europe. As Gregor (2010:89) states, "the 'dignified' production of Shakespearean drama, such that could compete with the very best of foreign productions of his work, was a possible vehicle for the recognition the regime so anxiously sought."

In light of these premises, Cayetano Luca de Tena's production of $\mathrm{Otelo}^{7}$ was first performed at the Español on $16^{\text {th }}$ December $1944 .^{8}$ This production was preceded by a propaganda campaign that started long before the premiere. The first step in promoting the play was the public reading offered by the translator, Nicolás González Ruiz, at the Español, which was attended by official representatives, on $3^{\text {rd }}$ November 1944. It was followed by a favourable critical reception, raising still more expectation among theatregoers. González Ruiz's version was said to have been "made with dignity, elegance of style and exact understanding of the requirements of the modern stage, something which always characterises the versions of foreign classics offered by the distinguished playwright, with impeccable taste, to the stage of our foremost coliseum" (de la Cueva 1944:n.p.). Secondly, on $11^{\text {th }}$ December 1944, official censorship approved the text without constraints for an audience of over 16 years old, claiming that Luca de Tena's direction and González Ruiz's translation guaranteed the success of the production, which was foreseen as another symbol of the savoir faire of the Spanish "national" theatre. The civil censor reported: "Nicolás González Ruiz's version is faithful to the dramatic line of the original, just pruning some pointless speeches. [...] Success is guaranteed. [...] It is another success in the series of great adaptations that the theatre is

\footnotetext{
${ }^{7}$ More details about this production can be found in the SHAKREP database: <www. um.es/shakespeare/representaciones>.

${ }^{8}$ In that same season, theatregoers could also attend the premiere of Fausto 43, an adaptation of Goethe's work by José Vicente Puente; Baile en Capitanía and Norte y Sur by Agustín de Foxá; and the national classics Fuenteovejuna and Don Juan Tenorio.
} 
currently offering to the Spanish audience."9 Besides, the ecclesiastical censor stated that "[t]he play, being old and wellknown by the learned audience, lacks, to my view, a noticeable pernicious influx. The uxoricide and suicide perpetrated by Otelo do not lead to imitation or acclaim. For these reasons, I consider that it can be authorised."

Then, one week before the opening night, Otelo was announced as the next event at the Español, news heard of the production and staging boding a theatre evening of supreme artistic interest for the following week. Finally, as anticipated, the success predicted by censors and critics was confirmed on the day of the premiere. From the theatre reviews of the period, it can be inferred that the audience acclaimed the self-censored, abridged and toned down González Ruiz's version directed by Luca de Tena with a standing ovation. Critics showered the production with praise: "superb staging," "impressive performance" (García Espina 1944:n.p), and "great and authentic success" (de O. 1944:n.p) are just a few of the countless compliments to the company of the Español. The play ran for more than eighty performances at a time when an average popular play was not on stage for more than fifty (González Ruiz 1948:206).

As a result, González Ruiz's translation became the authorised stage version of the tragedy during the period. Professional companies, such as José Tamayo's "Lope de Vega," usually performed it, ${ }^{10}$ whereas commercial theatre companies, such as Ramón Enguidanos's or Alejandro Ulloa's, adapted Astrana Marín's literary translation, probably to avoid legal issues concerning royalties. In this respect, it should be added that the Theatre Censorship Office banned the script submitted by Enguidanos in 1941 for its "lack of literary decency." ${ }^{11}$ Consequently, Enguidanos submitted a second text in 1942, which was included in the same file and approved with two crossings out relating to religious issues: "el

\footnotetext{
${ }^{9}$ Censorship files for this period are found in the Fondo de Cultura at the Archivo General de la Administración (AGA) in Alcalá de Henares, Madrid. For this particular report on Otelo, see AGA (03) 046, SIG 73/08607, File 650-44. All translations are mine.

${ }^{10}$ It was part of the repertoire of this company since 1946 and there is evidence of performances until 1957, when the play was staged at the Teatro Romano de Mérida as part of the Festivales al Aire Libre. José Tamayo directed the Español between 1954 and 1962.
}

${ }^{11}$ AGA (03) 046, SIG 73/o8338, File 2283-41. 
sacramento" and "el cielo se mofa de sí mismo."12 By contrast, the script signed by Alejandro Ulloa and Tomás Borrás to be performed at the Comedia theatre in Barcelona in 1957, which derived from Astrana's translation, was authorised for an audience over 16, the same report obtained by González Ruiz's text. In any case, Otelo was always staged according to the tenets of the regime through selfcensorship of controversial passages regarding politics, religion, sex and through the avoidance of indecorous language.

Although González Ruiz acknowledged in the theatre programme that he "ha[d] worked on the English text as it appears in John Hunter's reading text for British universities" (Otelo. 1944. Theatre Programme), his views on fidelity towards the original source were politically contaminated. ${ }^{13} \mathrm{He}$ was a supporter of the official censorship (González Ruiz 1987; Gregor and Bandín, forthc.), which he practised himself, and he firmly believed that classical works should be adapted to the tastes and tenets of the new cultural context: "classical works should be adapted so that the mass audience like them, in such a way that their timeless values do not disappear shrouded in a myriad of small circumstantial obstacles" (González Ruiz 1948:207). Thus, Nicolás González Ruiz freely translated the Shakespearean tragedy by purging "those circumstantial obstacles," for example, the explicit sexual references from the opening dialogue between Iago and Othello in IV.i. Nonetheless, it is worth highlighting that the self-censorship practised by the translator is not restricted to the Francoist context, as this passage had also been suppressed in earlier translations to avoid official censorship (Serrano 1988:18). In short, translators adjusted to the tradition practised by their predecessors. But González Ruiz also restrained himself in IV.ii by toning down all the insults uttered by Othello in a repetitive way and addressed to Desdemona: the English original "whore" was omitted or replaced by the less impolite Spanish expression "ramera" ('strumpet'), or by "mala mujer" ('bad woman'), and "public commoner" was omitted. ${ }^{14}$

\footnotetext{
${ }^{12}$ AGA (03) 046, SIG 73/08338, File 3162-42.

${ }^{13}$ It is likely that he refers to the edition by the Rev. John Hunter published by Longmans, Green and $\mathrm{C}^{\circ}$ in London in 1908.

${ }^{14}$ Many other examples could illustrate the practice of self-censorship carried out by González Ruiz, but this paper does not intend to provide a full textual analysis. See Bandín (2007) for a descriptive-comparative analysis.
} 
The first attempt to offer a new reading of the tragedy occurred in 1969, when theatre director Ángel Carmona produced an Othello "motivated by new meanings and allegories" (Primer Acto 1969:7) to be staged at the Romea theatre in Barcelona by La Pipironda theatre company. The performance text Otel-lo, based on the Catalan translation by Josep María de Sagarra, was authorised for an audience over 18 years old in view of the censors' reports: ${ }^{15} 1$ ) "The Catalan version by José María de Sagarra, being so pithy and rich, does transmit the original play with all its dramatic force. As long as it is an acclaimed classic, I feel bound to propose its approval for the general public;" 2) "The well-known play by Shakespeare in Sagarra's versification and for which the same report as the Castilian version should be issued." Despite state censorship's approval, Carmona did not succeed in transposing the Catalan version to the stage, to judge from the critical reaction. The reviewer of Primer Acto tells us how "the audience, or more exactly, part of the audience, soon started to show their disagreement, either with the actors' performance or with the director's approach to the tragedy. Carmona's supporters retorted and the play was interrupted. Curtain fell" (Primer Acto 1969:7). For the critic, "this interruption reveals that Saturn-like tragedy of self-devouring, while only in the next door theatre placid spectators support placid productions by placid authors in the service of placid criteria, which would be unimportant if they did not rule the current course of the Spanish theatre" (ibid.).

The decade of the seventies witnessed the decline of the regime. However, the thirst for continuity in a crumbling state brought a more repressive period in terms of censorship. The Ministry of Information and Tourism moved away from the so-called "opening" of Manuel Fraga Iribarne towards the repression exerted by his successor Alfredo Sánchez Bella. ${ }^{16}$ The direction of the Español was then placed in the hands of Alberto González Vergel from 1970 to 1976. ${ }^{17}$ The chosen play for his debut was La Estrella de Sevilla by

\footnotetext{
${ }^{15}$ Reports signed by Morales and Barceló. AGA (03) 046, SIG 73/09708, File 135-69.

${ }^{16}$ For a historical and political account of the dictatorship see Biescas and Tuñón de Lara (1980) and Tusell (1998).

${ }^{17}$ See Peláez (1993-1995). Before being put in charge of the Español theatre, Alberto González Vergel had directed the Murcia TEU. He also worked in RTVE for 30 years, and directed the mythical Estudio 1, a TV programme devoted to the production of
} 
Lope de Vega, first performed on $14^{\text {th }}$ October 1970, the next season being the turn for two more classical works: Medea and Othello. It was on $30^{\text {th }}$ October 1971 that Spaniards discovered a different reading of Othello on the national stage, this time with Marxist leanings. ${ }^{18}$ This was not the first time that González Vergel had turned a classical work into a social and political critique, slipping past the censors. In a recent interview, ${ }^{19}$ he confesses that his classical productions have always been political and sociological discourses: he set Medea in Peru in order to lash the Spanish colonial power, while La Estrella de Sevilla was a diatribe against absolute power and political tyranny. It caused such a great disturbance that the Theatre Censorship Office called him in to exclaim: ;nos has metido un gol! ("you've pulled the wool over our eyes!").

As opposed to previous productions of Othello, Alberto González Vergel's mise-en-scène, based on the text by Ángel Fernández Santos and Miguel Rubio, sought to displace romantic interpretations of the play by putting Iago at the forefront of the tragedy and presenting a sociological conflict, with both Othello and Iago as the oppressed victims of the capitalist system. The theatre text was submitted to the censors' approval and three different reports were issued..$^{20}$ The censor Barceló did not find any flaws in the new translation and, despite the fact that he had not compared it to previously submitted texts, he considered that the text should be approved as in other cases. However, Soria added that this new version took too many liberties and emphasised the harshness of some expressions. Thus, he proposed that the performance should be authorised for an audience of over 18 years old pending supervision of the dress rehearsal. Finally, Vázquez Dodero based his report on

plays. He is considered the doyen of our theatre directors, his Tiestes by Seneca being produced in the Teatro Romano de Mérida only last year.

${ }^{18}$ More details about this production can be found in the SHAKREP database: $<w w w$. um.es/shakespeare/representaciones>.

19 <http://www.laopinioncoruna.es/cultura/2010/o7/25/alberto-gonzalez-vergellorca-censuro-franco-familia-prohibio-representarlo-regimen/405183.html>.

[Consulted 20/02/2011].

${ }^{20}$ AGA (03) 046, SIG 73/09879, File 481-71. 
the comparison of the new theatre text with Luis Astrana Marín's translation and made two textual marks on the text: ${ }^{21}$

Page 27: "eso que llamamos amor es una mierda." (Astrana: "es un esqueje"). ["What we call love is shit." (Astrana: "it is a scion")].

Page 86: "puta" (Astrana: “impúdica"). ["whore." (Astrana: "indecent")].

He concluded that "the play be authorised for an audience over 14 by suppressing 'shit' and 'whore' (not educational at all) and replacing them with 'disgust' and 'outcast by life', since the translator gives the play an up-to-date tone." ${ }^{22}$ These were not the only examples of the many found in the text that illustrate how substantially modernised its language was. While in González Ruiz's version Desdemona was a "ramera" and a "mala mujer," here she is a "sucia ramera," a "zorra," a "puta" and a "cortesana."

The final report issued by the Theatre Censorship Office approved the performance for an audience over 18 years old, but pending a viewing of the dress rehearsal to ensure the appropriateness of the staging, as certain modern elements had been noticed in this new adaptation of Othello. The first innovation of the production was its length. Alberto González Vergel's Otelo, based on Ángel Fernández Santos and Miguel Rubio's adaptation, was advertised as the first full-length performance of the play in Spain, running for three hours and a half. The authors of this unabridged version justify their decision in the theatre programme that accompanied the performance:

If the Spanish spectator should have access to the great classical tragedies only when these have been previously doctored, and reduced for easy digestion, such behaviour implies the idea that the spectator is not, actually, an adult. Contrarily, our version of Othello is based on the opposite hypothesis: the Spanish spectator can and must face the entire poem without any kind of manipulation, without any sort of easiness. In the Spanish theatre jargon it is often said that the Spanish theatregoer cannot put up with a performance running for more than three hours. Going against this trend, the authors of this version of Othello try to ${ }^{21}$ Astrana Marín's translation was considered a "norm-model translation"
(Chesterman 1997:65) in the target context.

${ }^{22}$ AGA (03) 046, SIG 73/09879, File 481-71. 
demonstrate that such a convenient attitude to work is fictitious and it reflects falseness, under which a lazy intellectual attitude is to be lurking, harmful to the theatre professional and humiliating for the spectator. The most marked originality of this version of Othello is, for this reason, found in its comprehensive character. ${ }^{23}$

This innovation was welcomed by both critics and audience, as they were "three hours and a half immersed in that Shakespearian world: fabulous, brilliant, spine-chilling, hoarse, painful, cheerful, word for word, the magical power of language that can destroy the absurd and create entire worlds able to inflict on us a true catharsis" (Díez Crespo 1971:12). From the critic's view, González Vergel had achieved something very important because "it was nothing less than a restitution of Shakespeare, a rediscovery of the witty Englishman in the suitable context, devoid of clichés and mystifications" (ibid.). ${ }^{24}$ Although the three-hour performance was well received, critics did not unanimously praise the production as they did in 1944, voicing their disagreement with Gónzalez Vergel's sociological reading, as exposed in the theatre programme:

The romantic fake has reached indecent heights regarding the particularities of the great Iago, the core of the tragedy and, to certain extent, its absolute figure. The image of Iago as a personification of Evil, a kind of low class Mephistopheles, is still nowadays disrupting the real understanding of the fascinating personality of this man: a man of the people, a petty soldier gifted with an almost terrific intelligence and an extremely powerful sensibility, sharpened by being beaten everyday, to react against the oppression exerted over him. Iago is not a metaphysical

${ }^{23}$ Otelo. 1971. Theatre Programme. Teatro Español. Version by Ángel Fernández Santos and Miguel Rubio.

${ }^{24}$ González Vergel, as in Ducis's rendering, also considered that Othello was not black: "Because Othello is not - a new mistake of the Romantic iconography - a barbarous savage, is not the Beast who murders the Beauty inspired by Evil, is not Blackness desecrating Whiteness. Shakespeare makes no direct allusion to Othello being black. On the contrary, he only describes him as a Berber gentleman, with a dark skin burnt by an African sun able to dry the source of lowest passions. Othello is a Mauritian aristocrat who does not come from a savage tribe, but is a descendant of the Princes of the Desert; he comes from the caste of men who built the palaces of Granada and Marrakech, that is, a living depositary of probably the most refined culture in history. In other words, the opposite, the antipodes of the low business culture that spurs the Venetians, the first bourgeois of Europe" (Otelo. 1971. Theatre Programme. Teatro Español. Version by Ángel Fernández Santos and Miguel Rubio). 
villain, but a historical one, an oppressed man conscious of the oppression being exerted upon him, a tireless radical fighter who does not know - from his unavoidable perspective of a socially resentful person - any other fighting method than revenge. Iago pulled all the strings that set the tragedy in motion when his understanding of injustice made him feel outraged. Everything works around Iago to see in him the features of a premature revolutionary, a man provided with such a powerful critical apparatus that allows him to knock down, with invisible blows, that coarse order of coarse merchants which traps him.

The critic's reaction was to blame González Vergel for trying "to turn Shakespeare's Othello into a manifesto against the consumer society" and "a revolutionary flag of the oppressed peoples against those who usurp power in order to turn the former into slaves" (Gómez Picazo 1971:n.p.). Gómez Picazo ironically criticises "the weird interpretations that both theatre director and adaptors extract from the play" (ibid.), although he also remarks that it is not the first time that odd and made up readings are extracted from Shakespeare's Othello. Apart from the "unfortunate sociological additions," it was a great work and the performance was acclaimed by the public (Valencia 1971:n.p.).

Despite the objections made by censors and critics regarding the harshness of the language introduced in an attempt to modernise the text, the impressive staging of González Vergel's Otelo made a great impact on the present-day audience and on the Spanish stage, since, as Gregor remarks:
A theatrically more impressive, and, at the same time, authentically "Shakespearean" production in the period is hard to find. The willingness of director, set-designer and musician to emulate companies such as the Royal Shakespeare Company, although within the carefully encompassed boundaries of the contemporary Spanish stage, and with the limitations of the existing troupes, marked an important change of attitude to Shakespeare among the Spanish theatrical fraternity. (2010:100- 101)

The performance ran for six months and it broke box office records in Barcelona. After a long history of appropriation of the play to serve the propaganda interests of the regime, this innovative production was tolerated in the national theatre, almost thirty years 
after the doctored version by Nicolás González Ruiz was first performed.

To conclude, it can be said that both productions at the Español, in 1944 and in 1971, can be considered landmarks of the stage history of the play during the period, among other reasons, because they were staged at the "national theatre." Besides, they also show how the repressive force of state censorship did not just reside in its power to suppress conflicting passages but in the power exerted to promote certain theatrical traditions, while preventing theatre directors from offering new readings and updatings of the plays. Moreover, it can be seen that some critics contributed to the promotion of contemporary productions, bearing in mind that sometimes censor and critic were the same person. After thirty years of orthodox productions of Othello, González Vegel's sociological production of the play was passed. It is likely that censors did not understand its critical views on the capitalist system. Even if they did, Shakespeare was still exempt from censorship on the national stage, regardless of the period.

One of the conflicts that theatre translators and directors usually face is to choose the texts to be translated and staged (Zatlin 2005:12). In the cultural context of Franco's Spain, this conflict was stressed by the existence of a rigid state censorship mechanism. On the national stages the conflict also lay in offering new critical approaches to the classics. State censorship imposed a theatre tradition not only by purging the texts and watching over the staging carefully, but by accompanying the productions with a propaganda campaign to promote the "national theatre." The self-censored version by Nicolás González Ruiz played a central role in the Spanish theatre until Fernández Santos and Rubio revisited the play and offered the whole text divested of "the multiple lies and misrepresentations accumulating around the Romantic clichés that have been attached to the original dramatic text until the present." ${ }^{25}$ The 1971 production of Otelo implied an innovative view of the Shakespearean work for a Spanish cultural context that was timidly breaking with

${ }^{25}$ Otelo. 1971. Theatre Programme. Teatro Español. Version by Ángel Fernández Santos and Miguel Rubio. 
the preceding tradition and, at least, was a breath of fresh air on the national stage.

\section{References}

Biescas, José Antonio and Tuñón de Lara, Manuel 1980. Historia de España. Tomo X. España bajo la dictadura franquista (1939-1975). Barcelona: Labor.

Bandín Fuertes, Elena 2007. Traducción, recepción y censura de teatro clásico inglés. Estudio descriptivo-comparativo del Corpus TRACEtci (1939-1985). León: Universidad de León. (Unpublished PhD).

- 2008. "Translating at the Service of the Francoist Ideology: Shakespearean Theatre for the Spanish National Theatre. A Study of Paratexts." Eds. Micaela Muñoz-Calvo, Carmen Bueso-Gómez and $\mathrm{M}^{\mathrm{a}}$ Ángeles RuizMoneva. New Trends in Translation and Cultural Identity. Newcastle: Cambridge Scholars Press. 117-128.

Calvo, Clara 2006a. "De-foreignising Shakespeare: Otelo in Romantic Spain." Ed. José Manuel González Fernández de Sevilla. Spanish Studies in Shakespeare and his Contemporaries. Newark, DE: Delaware University Press. 117-129.

- 2006b. "Tragedia para reír: Grimaldi, Shakespeare y El Caliche o la parodia de Otelo." Eds. Francisco Lafarga and Luis Pegenaute. Traducción y Traductores: Del Romanticismo al Realismo. Berna: Peter Lang. 75-87.

Chesterman, Andrew 1997. Memes of Translation. Amsterdam, Philadelphia: John Benjamins.

González Ruiz, Nicolás 1948. "Las adaptaciones de clásicos a la escena actual." Bulletin of Spanish Studies 25/100: 206-213.

— 1987. "Una gran tarea de dignificación del teatro." Ed. Manuel L. Abellán. Censura y literaturas peninsulares. Diálogos Hispánicos de Ámsterdam, vol. 5. Amsterdam: Rodopi. 173-175.

Gregor, Keith 2002. "From Tragedy to Sainete: Othello on the Early Nineteenth-Century Spanish Stage." Shakespeare Yearbook 13: 322-341.

- 2007. "Shakespeare at the Español: Franco and the Construction of a National Culture." Multicultural Shakespeare 4: 29-36.

- 2010. Shakespeare in the Spanish Theatre. 1772 to the Present. London: Continuum.

Gregor, Keith and Bandín, Elena (forthc.). "The role of the censor in the reception of Shakespearean drama in Francoist Spain: the strange case of The Taming of the Shrew." Eds. Alberto Lázaro and Catherine O'Leary. Censorship Across Borders: The Censorship of English Literature in Twentiethcentury Europe. Newcastle: Cambridge Scholars Publishing. 
Serrano Ripoll, Ángeles 1988. Las traducciones de Shakespeare en España: el ejemplo de Othello. Valencia: Arcos.

Par, Anfós 1936-1940. Representaciones shakespearianas en España. 2 vols. Madrid: Librería General de Victoriano Suárez; Barcelona: Biblioteca Balmes.

Peláez, Andrés ed. 1993-1995. Historia de los teatros nacionales. Madrid: Instituto Nacional de las Artes Escénicas y la Música.

Tusell, Javier 1998. Historia de España en el siglo XX. III. La dictadura de Franco. Madrid: Taurus.

Zatlin, Phyllis 2005. Theatrical Translation and Film Adaptation. Clevedon: Multilingual Matters LTD.

\section{Theatre reviews}

de la Cueva, Jorge 1944. "Lectura en el Español. Una adaptación de «Otelo», de Shakespeare, por Nicolás González Ruiz." 4 November 1944: n.p.

de O. 1944. "Español. Estreno de «Otelo». Versión de Nicolás González Ruiz." 1971: n.p.

Díez Crespo, Manuel 1971. “Un gran «Otelo», en el Español.” El Alcázar 1 November 1971: 12.

García Espina, G. 1944. "Otelo, de William Shakespeare, en nueva versión de Nicolás González Ruiz." Informaciones 18 December 1944: n.p.

Gómez Picazo, E. 1971. “ «Otelo» de Shakespeare en rara versión.” 1971: n.p.

M., J. 1969. “Un «Otelo» inconcluso." Primer Acto 108: 7.

Valencia, Antonio 1971. “«Otelo», en el Español.” 1971: n.p.

How to cite this note:

Bandín Fuertes, Elena. "Performing Shakespeare in a Conflicting Cultural

Context: Othello in Francoist Spain." SEDERI 21 (2011): 119-132.

Author's contact: ebandin@um.es

Submission: 24/11/2010

Acceptance: 17/1/2011 